\title{
PERBEDAAN HASIL BELAJAR BIOLOGI SISWA MENGGUNAKAN MAKE A MATCH DAN WORD SQUARE KELAS XI IPA MAN 2 MODEL MEDAN T.A.2016/2017
}

\author{
Masni Nasution ", Uswatun Hasanah \\ Program studi Pendidikan Biologi, FMIPA, Universitas Negeri Medan, \\ Jl. Williem Iskandar Psr. V Medan Estate Fax. (061) 614002-613319, Medan, Indonesia, 20221 \\ *E-mail : t@gmail.com
}

\begin{abstract}
ABSTRAK
Tujuan dari penelitian ini adalah untuk mengetahui perbedaan hasil belajar kognitif siswa yang diajar menggunakan model pembelajaran Make a Match dengan Word Square pada materi Sistem Reproduksi Manusia di kelas XI IPA MAN 2 Model Medan T.A.2016/2017. Jenis penelitian ini adalah eksperimen semu (quasi experiment) dengan populasi penelitian seluruh kelas XI IPA MAN 2 Model Medan terdiri dari 10 kelas dengan jumlah siswa sebanyak 422 orang. Sampel penelitian ini dipilih dengan menggunakan teknik Purposive Sampling. Sampel terdiri dari tiga kelas yaitu kelas XI-IPA 4 yang berjumlah 43 orang sebagai kelas Make a Match, kelas XI-IPA 5 yang berjumlah 41 orang sebagai kelas Word Square, dan kelas XI-IPA 1 yang berjumlah 41 orang sebagai kelas kontrol. Instrumen penelitian berupa tes hasil belajar siswa berbentuk pilihan berganda yang berjumlah 40 soal yang sudah divalidasi terlebih dahulu. Untuk mengetahui perbedaan hasil belajar siswa digunakan uji-t. Berdasarkan uji persyaratan data diketahui bahwa data hasil penelitian berdistribusi normal dan ketiga kelas memiliki kesamaan varians (homogen). Dari analisis data diketahui bahwa nilai rata-rata siswa yang diajar dengan Make a Match adalah 92,372, yang diajar dengan Word Square adalah 91,22, dan yang diajar dengan Kontrol adalah 92. Ada perbedaan yang signifikan terhadap hasil belajar siswa, ini dibuktikan melalui uji-t pada taraf signifikan $\alpha=0,05$ dan $d k 82$ diperoleh $t_{\text {hitung }}>t_{\text {tabel }}(2,44>1,98)$ maka penelitian ini menolak $\mathrm{H}_{0}$ dan menerima $\mathrm{H}_{\mathrm{a}}$. Dengan demikian, dapat disimpulkan bahwa terdapat perbedaan hasil belajar siswa yang diajarkan dengan menggunakan model pembelajaran Make a Match dengan Word Square pada materi Sistem Reproduksi Manusia di kelas XI IPA MAN 2 Model Medan T.A.2016/2017.
\end{abstract}

Kata Kunci: Make A Match, Word Square, Hasil Belajar.

\section{ABSTRACT}

This aim of research is to know the difference of cognitive learning outcomes of students who are taught using learning model Make a Match with Word Square on the material of Human Reproduction System in class XI IPA MAN 2 Model Medan T.A.2016/2017. This research type is quasi experiment (quasi experiment) With the research population class XI IPA MAN 2 Model Medan consists of 10 classes with a total of 422 students. The sample of this research was chosen by using purposive sampling technique. The sample consists of three classes, namely class XI-IPA 4 which requires 43 people as a Make a Match class, XI-IPA 5 class which requires 41 people as Word Square class, and class XI-IPA 1 which requires 41 people as control class. The research instrument used is the result of multiple learning that requires 40 questions that have been validated first. To know the difference of learning result of student used t-test. Examined by the data of the study of normal distribution and middle class have the same variant (homogeneous). From the analytical data, it is known that the average student who is taught with Make a Match is 92,372, which is taught with Word Square is 91,22 , and the taught with Control is 92 . There is a significant difference to student learning outcomes, it is proved by - $t$ test At a significant level $\alpha=0.05$ and $d k 82 t_{\text {count }}>t_{\text {table }}(2.44>1.98)$ then this study rejects $H_{0}$ and receives $\mathrm{H}_{\mathrm{a}}$. Thus, it can be concluded by the differences in student learning outcomes that use the learning model Make a Match with Word Square on the material. Technology Science and Technology 2 Model Medan T.A.2016/2017.

Keywords: Make A Match, Word Square, Learning Outcomes.

\section{PENDAHULUAN}

Salah satu upaya untuk meningkatkan sumber daya manusia adalah melalui proses pembelajaran di sekolah, tepatnya dalam bidang pendidikan. Hasil belajar siswa di sekolah merupakan salah satu tolak ukur untuk mengetahui apakah suatu proses pembelajaran 
telah berjalan dengan baik atau tidak, sehingga dapat diketahui apakah tujuan dari pembelajaran tersebut telah tercapai atau belum. Dalam arti sederhana pendidikan sering diartikan sebagai usaha manusia untuk membina kepribadiannya sesuai dengan nilai-nilai di dalam masyarakat dan kebudayaan.

Seperti halnya pada kelas XI IPA MAN 2 Model Medan, setelah dilakukan observasi pada tanggal 19 Januari 2017 serta wawancara dengan guru biologi dan sebagian siswa, dapat diketahui bahwa proses pembelajaran yang diterapkan belum dapat mencapai tujuan pembelajaran secara maksimal. Pembelajaran yang diterapkan cenderung teacher center. Metode yang diterapkan guru antara lain ceramah, tanya jawab, diskusi dan pengamatan, namun yang lebih dominan digunakan adalah ceramah.

Permasalahan lain yang dialami oleh guru adalah masih banyak ditemui siswa yang kurang paham dengan materi yang disampaikan, namun tidak aktif bertanya atau berdiskusi dengan guru ataupun sesama siswa. Permasalahan ini memperlihatkan bahwa guru belum menggunakan metode yang tepat dalam menyelesaikan masalah pembelajaran tersebut. Khususnya pada materi Sistem Reproduksi Manusia. Materi Sistem Reproduksi Manusia merupakan materi biologi yang bersifat anatomis dan fisiologis (seperti submateri gametogenesis, menstruasi, fertilisasi dan gestrasi). Berdasarkan pengalaman guru, materi ini merupakan materi yang dianggap paling menarik oleh sebagian besar siswa. Materi yang menarik minat siswa untuk belajar ini belum tentu mudah untuk dipahami oleh siswa.

Berdasarkan hasil penelitian Utami dan Hasanah (2016:94) model pembelajaran kooperatif sangat cocok diterapkan pada pembelajaran biologi, karena dalam mempelajari biologi tidak cukup hanya mengetahui dan menghafal konsepkonsep tetapi juga dibutuhkan suatu pemahaman serta kemampuan menyelesaikan persoalan biologi dengan baik dan benar.

Berdasarkan penelitian mengenai model pembelajaran kooperatif tipe Make a Match yang dilakukan oleh Nasution dan Lazuardi (2016:21) menyatakan bahwa model pembelajaran kooperatif tipe Make a Match dapat meningkatkan hasil belajar siswa pada materi pokok sistem ekskresi pada manusia di kelas XI IPA MAN 1 Medan Tahun Pembelajaran 2015/2016 yang dapat digambarkan dari hasil postes dengan nilai rata-rata 87,56 dan standart deviasi 6,03. Berdasarkan penelitian yang dilakukan oleh Wahyuni dan Abidinsyah (2015:16) menyatakan bahwa model pembelajaran Word Square dapat meningkatkan hasil belajar siswa dimana terjadi peningkatan yaitu ketuntasan klasikal pada siklus I pertemuan $152,94 \%$ dan pada pertemuan 2 $62,86 \%$. Siklus II mengalami peningkatan ketuntasan klasikal pada pertemuan $183,87 \%$ dan pada pertemuan 2 sebesar 93,33\%.

Model pembelajaran yang akan diterapkan dalam penelitian ini adalah model pembelajaran kooperatif tipe Make a Match dan model pembelajaran kooperatif tipe Word Square dalam materi Sistem Reproduksi Manusia. Istarani (2012:63) mengungkapkan bahwa model pembelajaran tipe Make a Match itu sendiri adalah model pembelajaran yang menggunakan kartukartu dalam pembelajarannya, dimana kartu-kartu tersebut terdiri dari kartu-kartu berisi pertanyaanpertanyaan dan kartu-kartu lainnya berisi jawaban dari pertanyaan-pertanyaan tersebut. Sedangkan model pembelajaran tipe Word Square menurut Istarani (2012:181) merupakan model pembelajaran yang menggunakan kotak-kotak berupa teka-teki silang sebagai alat dalam menyampaikan materi ajar dalam proses belajar mengajar.

Berdasarkan uraian diatas dapat dilihat bahwa baik model pembelajaran Make a Match maupun Word Square sama-sama dapat meningkatkan hasil belajar siswa, oleh sebab itu penulis melakukan penelitian dengan judul "Perbedaan Hasil Belajar Biologi Siswa Menggunakan Make A Match dan Word Square Kelas XI IPA MAN 2 Model Medan T.A.2016 /2017."

\section{METODE PENELITIAN}

Penelitian ini dilaksanakan di MAN 2 Model Medan yang beralamat di Jalan Willem Iskandar No. 7 A Medan. Populasi yang dijadikan objek dalam penelitian ini adalah seluruh kelas XI-IPA MAN 2 Model Medan yang terdiri dari 10 kelas dengan jumlah siswa sebanyak 422 orang. Pengambilan sampel dilakukan dengan Random Sampling yaitu dengan mengambil 3 kelas sebagai sampel.

Jenis penelitian ini merupakan quasi experiment (eksperimen semu). Sampel yang diambil dalam penelitian akan diberi pretest untuk mengetahui kemampuan awal sampel. Setelah dilakukan pretest, kemudian kelas dikenai treatment dengan model pembelajaran Make a Match, Word Square dan Kontrol. Setelah itu, sampel diberikan post-test untuk mengukur hasil belajar kelas setelah dikenai treatment.

Prosedur dalam penelitian ini terdiri atas tahapan persiapan, pelaksanaan dan pengolahan data. Tahap persiapan meliputi mengadakan 
observasi ke sekolah tempat penelitian, meminta izin kepada kepala sekolah perihal kegiatan penelitian yang akan dilakukan, menyusun Proposal Penelitian dan mengikuti ujian seminar proposal.

Adapun tahap pelaksanaan yang telah dirancang sebagai berikut Menentukan kelas sampel dari populasi yang ada, melaksanakan tes awal (pretes) dengan bentuk tes objektif, yang dilakukan untuk melihat sejauhmana kemampuan siswa memahami konsep/materi pelajaran, Melakukan pengajaran dengan model pembelajaran kooperatif tipe Make a Match, Word Square dan Kontrol, kemudian memberikan tes akhir (pos tes) kepada kelas sampel untuk mengetahui hasil belajar siswa terhadap materi yang telah diajarkan. Melakukan pengolahan data tes akhir (postes). Menyimpulkan hasil penelitian.

Alat pengumpulan data yang digunakan untuk mengumpulkan data hasil belajar terhadap materi Sistem Reproduksi Manusia pada ranah kognitif adalah tes hasil belajar yang disusun dalam bentuk pilihan berganda (multiple choice) dengan jumlah 40 soal dan terdiri dari 5 pilihan jawaban yakni a, b, c, d, dan e.

Untuk mengetahui apakah ada perbedaan hasil belajar siswa menggunakan model pembelajaran kooperatif tipe Make a Match dan Word Square pada materi Sistem Reproduksi Manusia, maka dilakukan analisis data penelitian dari hasil tes yakni tingkat nilai hasil belajar, nilai rata-rata dan standart deviasi dan varians. Nilai hasil belajar dilihat dari nilai akhir (NA) siswa. Menghitung nilai akhir (NA) menurut Herisnawati, dkk (206:394) dapat dihitung sebagai berikut:

$$
\mathrm{NA}=\frac{\text { Jumlah jawaban benar }}{\text { Jumlah soal }} \times 100
$$

Menghitung nilai rata-rata (mean) kedua kelas yang dikutip dari Sudjana (2005:67) dengan rumus:

$$
\bar{X}=\frac{\sum X i}{n}
$$

Keterangan:

$\bar{X} \quad=$ Mean (rata-rata)

$\sum X i=$ Jumlah nilai siswa

$n \quad$ = Jumlah siswa

Standart deviasi merupakan akar dari varians. Menghitung varians menurut Sudjana (2005:94), dengan menggunakan rumus:

Keterangan:

$$
\mathrm{S}^{2}=\frac{n \sum X i^{2}-\left(\sum X i\right)^{2}}{n(n-1)}
$$

$\mathrm{S}^{2} \quad=$ Varians

$$
\begin{aligned}
& \Sigma \mathrm{Xi}^{2}=\text { Jumlah kuadrat nilai total } \\
& (\Sigma \mathrm{Xi})^{2}=\text { Jumlah nilai total } \\
& \text { dikuadratkan } \\
& \mathrm{n} \quad=\text { Jumlah siswa } \text {. }
\end{aligned}
$$

\section{HASIL PENELITIAN}

\section{Deskripsi Hasil Belajar Siswa Menggunakan Model Make a Match}

Hasil postes siswa pada kelas XI-IPA 4 (Make a Match) diperoleh nilai rata-rata 94,13 dan standart deviasi 5. Nilai postes pada kelas XI-IPA 4 (Make a Match) dapat dilihat pada Tabel 1 dibawah ini.

Tabel 1. Nilai Postes Kelas XI-IPA 4 (Make a Match)

Kelas XI-IPA 4

(Make a Match)

\begin{tabular}{cccc}
\hline Nilai Postes & F & Rata-rata & SD \\
\hline 84 & 2 & & \\
\cline { 1 - 2 } 88 & & & \\
\cline { 1 - 2 } 92 & 94,13 & 5 \\
\cline { 1 - 2 } 96 & 10 & & \\
\cline { 1 - 2 } 100 & 11 & & \\
\hline Jumlah & 43 & & \\
\hline
\end{tabular}

Berdasarkan Tabel 1. diperoleh nilai rata-rata postes kelas XI-IPA 4 (Make a Match) sebesar 94,13 dan standart deviasi 5 dengan nilai tertinggi 100 sebanyak 12 orang dan nilai terendah 84 sebanyak 2 orang.

\section{Deskripsi Hasil Belajar Siswa Menggunakan Model Word Square}

Hasil postes siswa pada kelas XI-IPA 5 (Word Square) diperoleh nilai rata-rata 91,22 dan standart deviasi 6 . Nilai postes pada kelas XI-IPA 5 (Word Square) dapat dilihat pada Tabel 2 dibawah ini.

Tabel 2. Nilai Postes Kelas XI-IPA 5 (Word Square)

Kelas XI-IPA 5

(Word Square)

\begin{tabular}{cccc}
\hline Nilai Postes & $F$ & Rata-rata & SD \\
\hline 72 & 1 & & \\
\cline { 1 - 2 } 80 & 2 & & \\
\cline { 1 - 2 } 84 & 3 & & \\
\cline { 1 - 2 } 88 & 11,22 & 6 \\
\cline { 1 - 2 } 92 & 9 & & \\
\hline 96 & 10 & & \\
\hline 100 & 5 & & \\
\hline Jumlah & 41 & &
\end{tabular}

Berdasarkan Tabel 2. diperoleh nilai ratarata postes kelas XI-IPA 5 (Word Square) sebesar 91,22 dan standart deviasi 6 dengan nilai tertinggi 
100 sebanyak 5 orang dan nilai terendah 72 hanya 1 orang.

\section{Deskripsi Hasil Belajar Siswa Menggunakan Kontrol}

Hasil postes siswa pada kelas XI-IPA 1 (Kontrol) diperoleh nilai rata-rata 92 dan standart deviasi 6,41. Nilai postes pada kelas XI-IPA 1 (Kontrol) dapat dilihat pada Tabel 3 dibawah ini. Tabel 3. Nilai Postes Kelas XI-IPA 1 (Kontrol)

\begin{tabular}{|c|c|c|c|}
\hline \multicolumn{4}{|c|}{$\begin{array}{c}\text { Kelas XI-IPA } 1 \\
\text { Kontrol }\end{array}$} \\
\hline Nilai Postes & $F$ & Rata-rata & SD \\
\hline 72 & 1 & & \\
\hline 76 & 1 & & \\
\hline 80 & 1 & & \\
\hline 84 & 2 & & \\
\hline 88 & 10 & 92 & 6,41 \\
\hline 92 & 9 & & \\
\hline 96 & 11 & & \\
\hline 100 & 6 & & \\
\hline Jumlah & 41 & & \\
\hline
\end{tabular}

Berdasarkan Tabel 3. diperoleh nilai rata-rata postes kelas XI-IPA 1 (Kontrol) sebesar 92 dan standart deviasi 6,41 dengan nilai tertinggi 100 sebanyak 6 orang dan nilai terendah 72 hanya 1 orang.

\section{Perbedaan Hasil Belajar Siswa Menggunakan Model Make a Match dengan Word Square}

Berdasarkan perhitungan yang telah dilakukan, diketahui nilai rata-rata postes kelas XIIPA 4 (Make a Match) adalah 94,13 dan standart deviasi 5 sedangkan nilai rata-rata postes XI-IPA 5 (Word Square) adalah 91,22 dan standart deviasi 6. Nilai $t_{\text {hitung }}$ yang diperoleh sebesar 2,44 selanjutnya dibandingkan dengan nilai $t_{\text {tabel }}$ dengan $\mathrm{dk}$ (82) dan taraf signifikan $\alpha=0,05$ adalah 1,98 . Hasil perbandingan diketahui bahwa $\mathrm{H}_{0}$ ditolak sekaligus menerima $\mathrm{H}_{a}$ yang berarti ada perbedaan hasil belajar siswa menggunakan model pembelajaran Make a Match dengan Word Square pada materi Sistem Reproduksi Manusia dikelas XI-IPA MAN 2 Model Medan T.A.2016/2017.

\section{PEMBAHASAN}

Berdasarkan hasil pretes diketahui nilai ratarata siswa pada kelas XI-IPA 4 (Make a Match) sebesar 37,76, nilai rata-rata siswa pada kelas XIIPA 5 (Word Square) sebesar 35,8 dan nilai rata rata siswa pada kelas XI-IPA 1 (Kontrol) sebesar 35,41 . Hasil pretes ini menunjukkan bahwa hasil belajar siswa sebelum diberikan perlakuan dengan menggunakan model pembelajaran yang berbeda masih tergolong rendah. Hal tersebut dikarenakan siswa belum menerima pembelajaran tentang materi pokok sistem reproduksi manusia dari guru.

Sementara dari hasil postes diketahui nilai rata-rata siswa pada kelas XI-IPA 4 (Make a Match) sebesar 94,13, nilai rata-rata postes pada kelas XI-IPA 5 (Word Square) sebesar 91,22 dan nilai rata-rata postes pada kelas XI-IPA 1 (Kontrol) sebesar 92. Nilai rata-rata hasil belajar siswa pada ketiga kelas penelitian setelah diberikan perlakuan dengan menggunakan model pembelajaran yang berbeda diketahui bahwa nilai hasil belajar siswa untuk kelas XI-IPA 4 (Make a Match) lebih tinggi dari pada hasil belajar siswa untuk kelas XI-IPA 5 (Word Square) dan kelas XI-IPA 1 (Kontrol). Hasil belajar siswa pada materi pokok Sistem Reproduksi Manusia yang diajarkan dengan menggunakan model Make a Match lebih baik dibandingkan dengan hasil belajar siswa yang diajarkan dengan model Word Square. Hasil ini didukung oleh penelitian Ali (2010:36) yang menyatakan bahwa telah terjadi peningkatan hasil belajar biologi siswa yakni pada akhir tindakan pada setiap siklus kenaikan pencapaian hasil belajar siswa termasuk tinggi, yakni sebelum dilakukan tindakan hasil belajar siswa rata-rata 50, siklus | 62,05, siklus II 72,03 dan setelah akhir tindakan pada siklus II menjadi 78,55.

Pada dasarnya penggunaaan metode/strategi/model belajar merupakan salah satu indikator penting yang menentukan hasil belajar siswa. Selanjutnya Istarani (2012:1), menambahkan model pembelajaran adalah "seluruh rangkaian penyajian materi ajar yang meliputi segala aspek sebelum, sedang dan sesudah pembelajaran yang dilakukan guru serta segala fasilitas yang terkait secara langsung atau tidak langsung dalam proses belajar mengajar". Perbedaan peningkatan hasil belajar tersebut juga terlihat dari tingkat ketuntasan belajar siswa, dimana pada kelas dengan menggunakan model Make a Match hanya terdapat 2 orang siswa yang memperoleh nilai dibawah 85, sedangkan pada kelas yang menggunakan model Word Square terdapat 6 orang siswa yang memperoleh nilai dibawah 85, dan pada kelas Kontrol hanya terdapat 5 orang siswa yang memperoleh nilai dibawah 85. Hasil tersebut menunjukkan bahwa meskipun sama-sama meningkatkan hasil belajar siswa, namun penggunaan model pembelajaran Make a Match masih lebih baik digunakan untuk meningkatkan hasil belajar siswa pada materi sistem reproduksi manusia. Hasil ini didukung oleh penelitian Nasution dan Lazuardi (2016:21) yang menyatakan bahwa model pembelajaran 
kooperatif tipe Make a Match dapat meningkatkan hasil belajar siswa pada materi pokok sistem ekskresi pada manusia di kelas XI IPA MAN 1 Medan Tahun Pembelajaran 2015/2016 yang dapat digambarkan dari hasil postes, yaitu nilai rata-rata 87,56 dan standart deviasi 6,03.

Dari pengamatan peneliti selama melaksanakan penelitian, terjadinya perbedaan hasil belajar siswa antara lain karena timbul suasana yang menyenangkan saat belajar dengan menggunakan model pembelajaran kooperatif tipe Make a Match. Model pembelajaran kooperatif tipe Make a Match sangat bermanfaat terhadap kemampuan siswa dalam mengerjakan soal sehingga hasilnya meningkat, karena dapat melatih ketrampilan cara berfikir siswa pada saat mencocokkan kartu pertanyaan dan kartu jawaban, serta dapat membantu siswa dalam mengingat mengenai poin-poin penting dalam materi sistem reproduksi manusia, memahami lebih dalam melalui gambar yang disediakan dalam kartu, membantu siswa dalam kemampuan menguraikan dan menggali lebih dalam informasi dalam sebuah materi, dan siswa dapat melatih kerja sama di dalam kelompoknya, sehingga masing-masing siswa dapat berperan aktif. hal ini sejalan dengan pendapat Istarani (2012:65), yang menyatakan bahwa pembelajaran Make a Match baik digunakan manakala guru menginginkan kreativitas berfikir siswa, sebab melalui pembelajaran seperti ini siswa diharapkan mampu untuk mencocokkan pertanyaan dengan jawaban yang ada didalam kartu dan siswa terlibat langsung daam menjawab soal yang disampaikan kepadanya melalui kartu. Penggunaan model pembelajaran Make a Match ini juga dapat menghindari kejenuhan siswa dalam mengikuti proses belajar mengajar dikelas. Pendapat ini juga didukung oleh hasil penelitian Masrikhah (2014:77) bahwa model pembelajaran Make a Match mampu meningkatkan hasil evaluasi tertulis sebesar $102 \%$, disertai meningkatnya KKM mencapai $84 \%$. Selain itu metode ini juga dapat meningkatkan keterampilan dan kreativitas siswa sebesar 5\%.

Sedangkan pada kelas yang diberikan pengajaran dengan model Word Square meskipun terlihat antusias siswa dalam belajar, namun dengan model pembelajaran ini siswa terkesan individual sehingga siswa-siswi tersebut tidak memperoleh informasi yang utuh mengenai materi yang disajikan. Kemudian salah satu kekurangan model ini adalah membutuhkan waktu yang lama bagi siswa untuk mencari jawaban pada kotakkotak yang telah dipersiapkan. Dan pada kelas kontrol, kegiatan pembelajarannya hanya menggunakan metode ceramah saja. Saat pembelajaran berlangsung siswa merasa jenuh karena cenderung monoton sehingga siswa kurang termotivasi dalam mengikuti pembelajaran karena model pembelajaran tersebut menyebabkan siswa hanya menerima informasi dan masih banyak siswa yang belum bisa mengemukakan pendapat maupun menggali pertanyaan yang diberikan oleh guru.

Berdasarkan hasil pengujian hipotesis diketahui bahwa $t_{\text {hit }}>t_{\text {tab }}(2,44>1,98)$ sehingga dalam penelitian ini $\mathrm{H}_{0}$ ditolak sekaligus menerima $\mathrm{H}_{\mathrm{a}}$. Jadi dapat disimpulkan bahwa ada perbedaan hasil belajar siswa dengan menggunakan model pembelajaran Make a Match dengan Word Square pada materi sistem reproduksi manusia dikelas XIIPA MAN 2 Model Medan T.A.2016/2017. Maka dapat dinyatakan bahwa model Make a Match lebih baik digunakan untuk mengajarkan materi sistem reproduksi manusia dibandingkan dengan model Word Square.

\section{KESIMPULAN}

Terdapat perbedaan antara hasil belajar siswa yang diajar menggunakan model pembelajaran Make a Match dengan Word Square pada materi sistem reproduksi manusia dikelas XIIPA MAN 2 Model Medan T.A.2016/2017.

\section{UCAPAN TERIMA KASIH}

Ucapan terimakasih penulis ucapkan kepada Kepala Sekolah MAN 2 Modl Medan bapak Drs Dr. H. Burhanuddin, M.Pd dan Ibu Ida Iriani, S.Pd, M.Pd selaku guru Biologi yang telah banyak membantu penulis sewaktu melaksanakan penelitian.

\section{DAFTAR PUSTAKA}

Ali, H., (2010), Peningkatan Hasil Belajar Biologi Siswa Melalui Penggunaan Model Pembelajaran Kooperatif Make A Match Pada Konsep Reproduksi Manusia Di Kelas IX B SMP Negeri 2 Pangsid, Bionature, 11 (1): 29-36.

Herisnawati., Nurhidayati, S., dan Wijayanti, TS., (2010), Pengaruh Metode Make A Match Terhadap Aktivitas, Minat Dan Hasil Belajar IPA Siswa Kelas VIII MTS Darussalam Bermi Lombok Barat, Prisma Sains, 3(2): 392-398.

Istarani, (2012), 58 Model Pembelajaran Inovatif, Media Persada, Medan. 
Halaman : $049-054$

Masrikhah, R., (2014), Make A Match In Cooperative Learning Untuk Meningkatkan Pemahaman Materi Protista Pada Siswa SMA, Bioma, 3(2):7689.

Nasution, ERA., dan Lazuardi., (2014), Perbandingan Hasil Belajar Siswa Dengan Menggunakan Model Pembelajaran Kooperatif Tipe Make A Macth dan Scrambel Pada Materi Pokok Sistem Ekskresi Manusia Di Kelas XI IPA MAN 1 Medan, Jurnal Pelita Pendidikan, 4(3):016022.

Sudjana, (2005), Metode Statistika, Tarsito, Bandung.

Utami, M., dan Hasanah, U., (2016), Perbedaan Hasil Belajar Siswa Menggunakan Model Pembelajaran Kooperatif Tipe Think Pair Share (TPS) dengan Student Team Achievement Division (STAD) pada materi ekosistem, Jurnal Pelita Pendidikan, 4(2):093-099.

Wahyuni, AK., dan Abidinsyah., (2015), Meningkatkan Hasil belajar dengan Model Pembelajaran Kooperatif Tipe Word Square, Jurnal Pendidikan Hayati, 1(1): 1622. 